\title{
AsYNCHRONOUS MEASUREMENT OF CDV IN ATM NETWORKS USING OAM CELLS
}

\author{
J. GARCÍA-HERNÁNDEZ ${ }^{1}$, M. GHANBARI ${ }^{2}$ \\ ${ }^{1}$ Instituto de Investigaciones Eléctricas, Gerencia de Control e Instrumentación, Av. Reforma No. 113, Col. Palmira, Temixco, Mor., \\ México, E-mail: jgarciah@iie.org.mx \\ ${ }^{2}$ The University of Essex, Department of Electronic Systems Engineering, Wivenhoe Park, Colchester, CO 4 3SQ, United Kingdom
}

Received October $22^{\text {th }} 2001$ and accepted June $27^{\text {th }} 2002$

\section{ABSTRACT}

The synchronisation between source and destination clocks at network nodes to a common reference time of day is important in order to achieve accurate measurements of cells delays in ATM networks. Otherwise, direct measurement of the cell transfer delay and cell delay variation using time-stamped OAM cells would be inaccurate. In this work, a method for the accurate measurement of cell delay variation using OAM cells, which does not rely on synchronised clocks at the measurement points is presented. This is achieved by assuming that each ATM switch has the capability to process and to modify the information contained in the OAM cells. The system presented here was modelled by means of a block-oriented network simulator (BONeS), which is a graphically-oriented, generalpurpose simulation language for modelling and simulating communications networks, including ATM networks. The measurements of the cell delay variation were carried out on a VBR video source generated by a real MPEG-2 encoder with a fixed quantizer step size. The simulation results obtained show that measurements of the cumulative cell delay variation carried out without synchronised clocks at the measurement points were very closed to those obtained using synchronised clocks at the measurement points.

\section{RESUMEN}

La sincronización entre los relojes fuente y destino en nodos de red a una hora del día, es importante para obtener mediciones exactas del retardo de celdas en redes ATM. De lo contrario, la medición directa de la variación del retardo de celdas usando estampas de tiempo en celdas OAM resultaría inexacta. En este artículo, se presenta un método para medir con exactitud la variación del retardo de celdas en redes ATM usando celdas OAM, el cual no requiere de sincronización de relojes entre los puntos de medición. Esto es obtenido, considerando que cada switch ATM tiene la capacidad para procesar y modificar la información contenida en las celdas de monitoreo OAM. El sistema presentado aquí fue modelado por medio de un simulador de redes orientado a bloques (BONeS), el cual permite modelar y simular redes de comunicaciones, incluyendo redes ATM. Las mediciones fueron realizadas utilizando una fuente de video del tipo VBR, generado por un codificador MPEG-2 real con un cuantizador de paso fijo. Los resultados de simulación muestran que las mediciones de la variación acumulativa del retardo de celdas, realizadas sin la sincronización de relojes entre los puntos de medición, fueron muy similares a aquellas obtenidas usando relojes sincronizados entre los puntos de medición.

KEYWORDS: Operation and Maintenance (OAM), Cell Delay Variation (CDV), Variable Bit Rate (VBR), Quality of Service (Q oS). 


\section{INTRODUCTION}

In ATM networks, the information is asynchronously transmitted using virtual connections where cells follow a fixed route and their sequence integrity is respected. Cells are forwarded from one switch to another along the ATM connection. Due to queuing, cells of a given connection experience different transfer delays along the network. This phenomenon is referred as Cell Delay Variation (CDV) [1,2]. Because of the asynchronous nature of the ATM technique, CDV is a critical Q oS parameter in ATM networks [3], especially for real-time applications where source and destination are required to remain synchronised [4].

In ATM networks, in-service monitoring methods are based on operation and maintenance (OAM) cells. The in-service performance monitoring technique proposed in standards $[5,6]$ for ATM networks, consists of the insertion of OAM cells between blocks of $\mathrm{N}$ user cells at any virtual path or virtual channel termination or connecting point, and then may be copied or extracted at any similar point at the end of the connection or the segment being monitored, as Figure 1 illustrates. Each OAM cell contains information about its preceding block of user cells. At the destination, this information is compared with the received block of user cells in order to estimate Q oS parameters such as cell transfer delay, cell delay variation, cell loss ratio, etc. [7, 8].

OAM cell

(Forwand monitoring) Block of N user cells

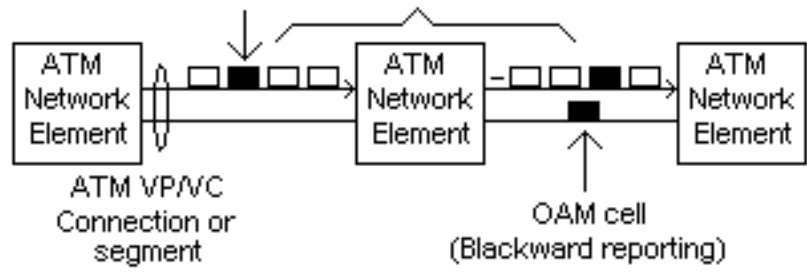

Figure 1. In-service performance monitoring method.

This information may be locally recorded and/or to the source node using an OAM cell by activating the backward reporting function [9-11], as illustrated in figure 2. The recommended block sizes (N) are 128, 256, 512, and 1024 user cells.

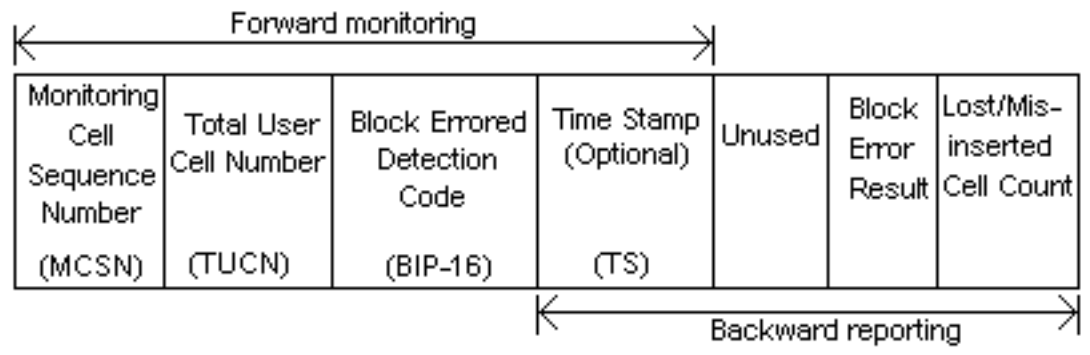

Figure 2. Performance monitoring OAM cell.

From figure II, we can observe that "time stamp" (TS) is an optional field, but it may be used to represent the time at which the OAM cell was inserted, so it is intended to be used for cell delay measurements. We used this field to measure the Q oS parameter CDV.

\section{SYNCHRO NOUS MEASUREMENT OF THE CDV USING OAM CELLS}

To measure the end-to-end cell delay variation using the method above mentioned, the following procedure was used: at the source node, the transmitted OAM cell payload contains the time at which the cell was transmitted. The destination node subtracts this time from the time at which the cell was received to determine the cell transfer delay for that cell. Then, individual measurements of cell transfer delays are used to calculate the statistics of the cell transfer 
delay distribution (mean, variance, etc.) and consequently to obtain the CDV. We define the CDV [12], as the standard deviation of cell transfer delays observed at the output of a connection endpoint with reference to the input of that connection endpoint:

$$
C D V=\sqrt{\frac{\sum(C T D i-\overline{C T D})^{2}}{N}}
$$

Where, CTD $i$ is the transfer delay of the ith cell of the connection, CTD is the mean value of the cell transfer delay, and $N$ is the total number of cells transmitted. When the measurement points are the source and the destination nodes, we call this measure end-to-end CDV. Likewise, when the measurement points are the input and the output of an ATM switch, we call this measure local CDV. In this OAM-based performance monitoring procedure, intermediate switches are not allowed to process the information contained in the OAM cells. They simply relay OAM cells without modifying or adding information. Also, according to the standards, this method requires synchronised clocks to the same time of day at the measurement points [13]. In an ATM network composed of a number of nodes, if the time of day distribution (TOD) among network nodes were accurate, the TOD error (difference in time between source and destination clocks) would be zero. However, in practice, the TOD error can be by the order of a few seconds [14]. Therefore, the synchronisation between source and destination clocks at network nodes to a common reference time of day is important to achieve accurate measurements of cell delays in ATM networks. Otherwise, direct measurement of the cell transfer delay and cell delay variation using time-stamped OAM cells would be inaccurate [14]. A common approach to synchronisation is the use of the Global Positioning System (GPS), which involves the reception of radio signals of 24 satellites [15]. However, for B-ISDN networks with a large number of nodes, this solution would be expensive. In the following section, a method for the accurate measurement of the cell delay variation using timestamped OAM cells, which does not rely on the availability of synchronised clocks to the same time of day at the measurement points is introduced.

\section{ASYNCHRONOUS MEASUREM ENT OF THE CDV USING OAM CELLS.}

To measure accurately the end-to-end cell delay variation using OAM cells, without the need for clock synchronisation between the measurement points, as required in the current OAM-based performance monitoring procedure, the following procedure was used: the input-to-output OAM cell delays are computed at each ATM switch, using time stamps. This is done by time stamping each received OAM cell at a switch input, and reading the time stamp before it leaves the switch. The difference between the input and output times (input-to-output delay) is stored in an empty field in the OAM cell before it is transmitted. Here, each ATM switch is provided with external capabilities to process and to modify the information contained in the OAM cells with the information collected by each switch. As the OAM cells pass through each switch, the time stamp fields in the OAM cell accumulate the cell transfer delays measured at every switch along the connection. The fixed propagation delays were previously calculated and added at each ATM switch. At the destination, the last time stamp field recorded the value of the end-to-end cell transfer delay experienced by the OAM cells along the ATM connection. Then, individual measurements of end-to-end cell transfer delays were used to calculate the end-to-end CDV, using the formula (1).

\section{EXPERIMENTS DESCRIPTION}

This section compares the methods explained in sections 2 and 3, which allow the measurement of the end-to-end CDV using time-stamped OAM cells, with and without synchronised clocks at the measurement points. To do that, the end-to-end CDV was measured in an ATM network in two scenarios, by using simulation. In the first system, the cumulative CDV (CDV0, CDV1, etc.) was measured from the source node (reference measurement point) to the output of each ATM switch (including the associated fixed propagation delays) using time-stamped OAM cells, as illustrated in figure 3. The cumulative CDV measured between the source and destination nodes corresponds to the end-to-end CDV. 


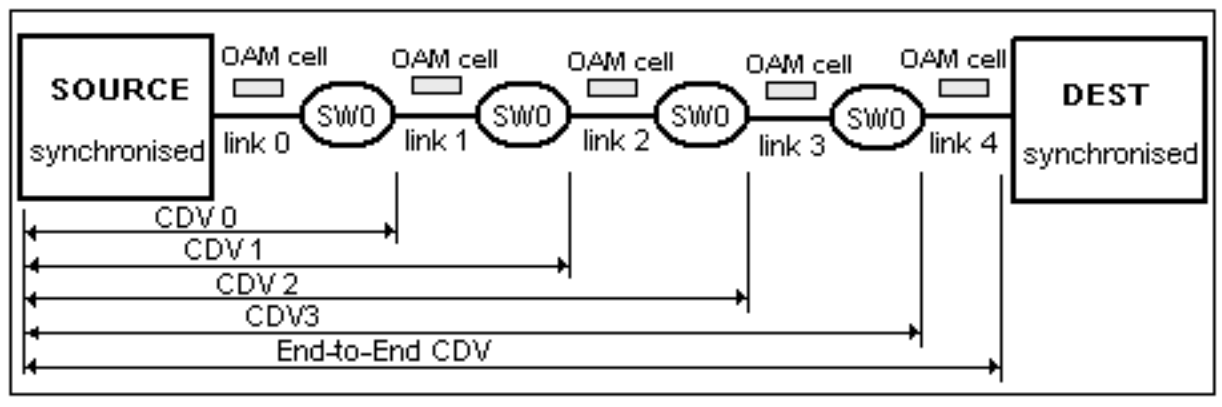

Figure 3. Measurement of the CDV with synchronised clocks.

In this experiment, intermediate ATM switches were not allowed to process the information contained in the OAM cells. They simply relayed the OAM cells without modifying or adding information. Also, the source and destination clocks at the measurement points, were synchronised to the same time of day.

In the second system, in order to measure the end-to-end CDV, the input-to-output cumulative cell delays (D0, D1, etc.) were measured at every ATM switch using time-stamped OAM cells. Then, the associated fixed propagation delays (previously calculated) were added to the measured cell delays and the resulting cell transfer delays (CTD0, CTD1, etc.) were stored in empty OAM cell fields. For example, the first switch stores the CTD0 in the field 0, the second switch stores the value that results from adding CTD0 to CTD1 in the field 1, and so on, as figure 4 illustrates. At the destination, the end-to-end CTD and consequently the end-to-end CDV were obtained and computed. The cumulative CDV measured at the destination node corresponds to the end-end CDV.

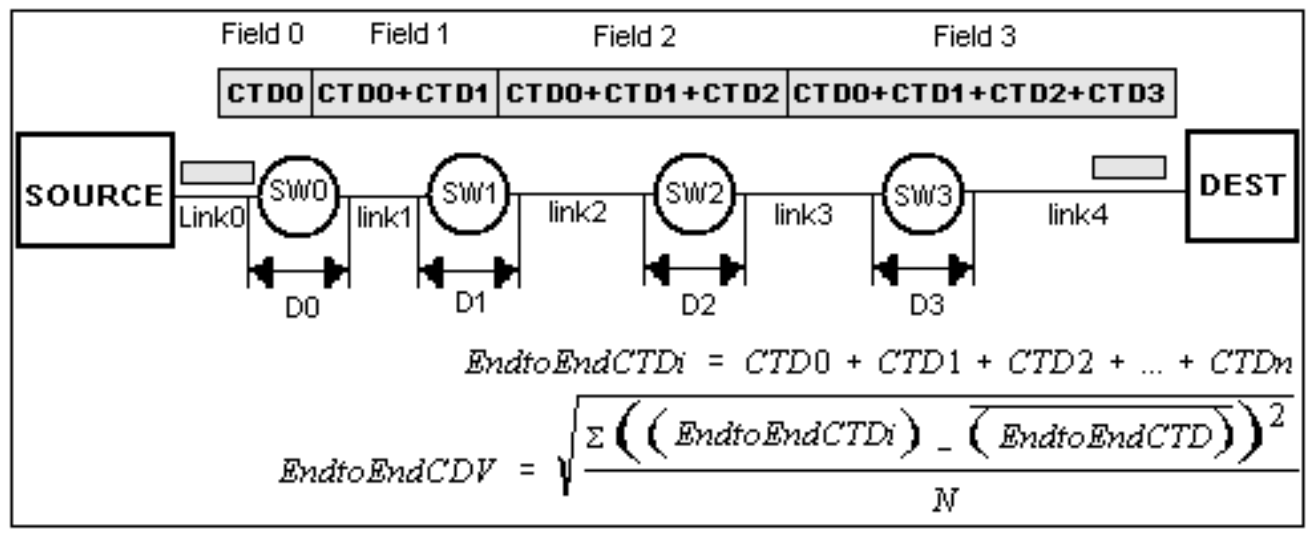

Figure 4. Measurement of the CDV without synchronised clocks.

In this experiment, each ATM switch was provided with external capabilities to process and to modify the information carried out by the OAM cells. Also, the source and destination clocks at the measurement points, were not synchronised to the same time of day.

\section{SIMULATION RESULTS AND CONCLUSIONS}

Figures 5, 6, and 7 show the simulation results obtained from measuring the cumulative CDV using time-stamped OAM cells, with and without synchronised clocks at the measurement points, for ATM network configurations of 4, 8, and 16 ATM switches connected in tandem. The system presented in figures 3 and 4 was modelled by means of a block-oriented network simulator (BONeS) software, which is a graphically-oriented, general-purpose simulation language for modelling and simulating communications networks, including ATM networks [3, 16]. The measurements of the CDV were carried out on a VBR video source of $5 \mathrm{Mb} / \mathrm{s}$. The traffic of the VBR video source was generated by a real MPEG-2 encoder with a fixed quantizer step size. The quantizer step size was chosen such that SIF (source intermediate format) image sequences ( $352 \times 288$ lines, $25 \mathrm{~Hz}$ ) were coded at a mean bit rate of 
approximately $5 \mathrm{Mb} / \mathrm{s}$. Also, for the purpose of measuring the cell transfer delay and cell delay variation on the VBR video source, buffers of all ATM switches were chosen large enough to avoid congestion. The network load was chosen to be 0.7 in all links, along with an insertion rate of 1 OAM cell for every 128 user cells.

All figures show that the measurements of the cumulative CDV carried out without synchronised clocks at the measurement points were very closed to the results obtained from the measurement of the cumulative CDV using synchronised clocks at the measurement points.

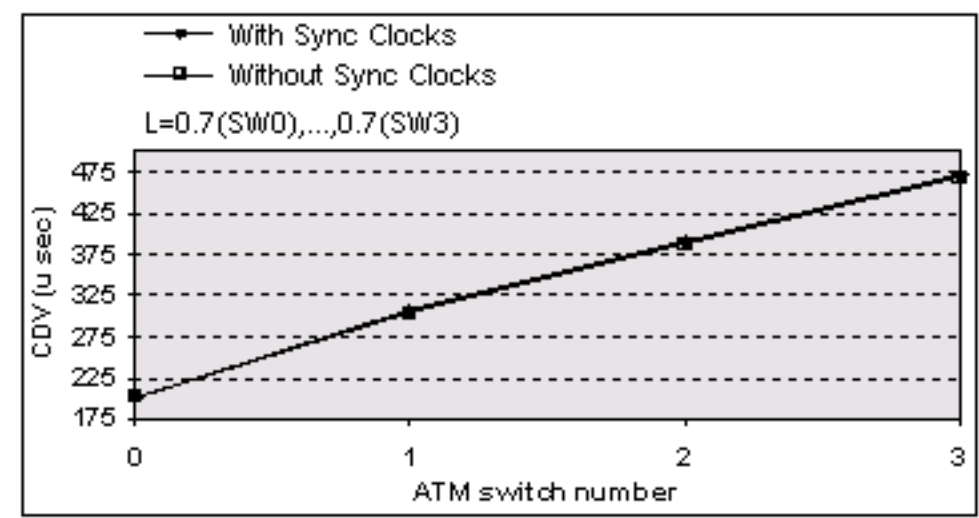

Figure 5. Cumulative CDV measured by using 4 ATM switches.

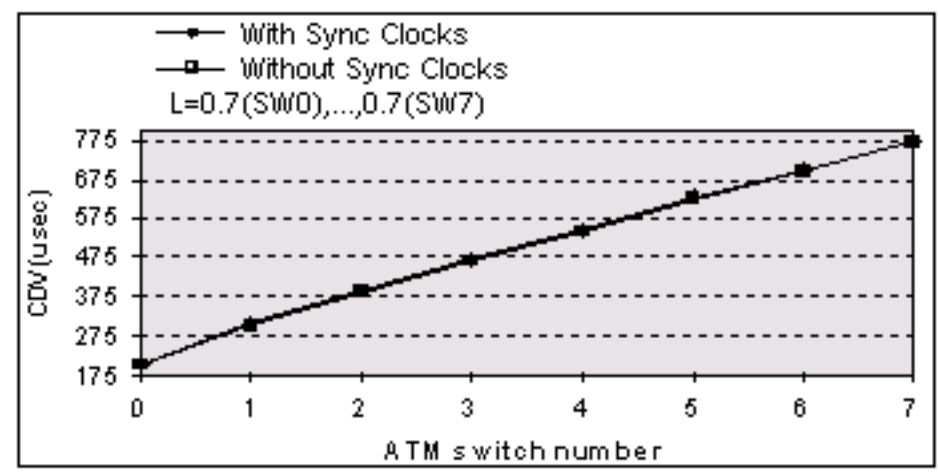

Figure 6. Cumulative CDV measured by using 8ATM switches.

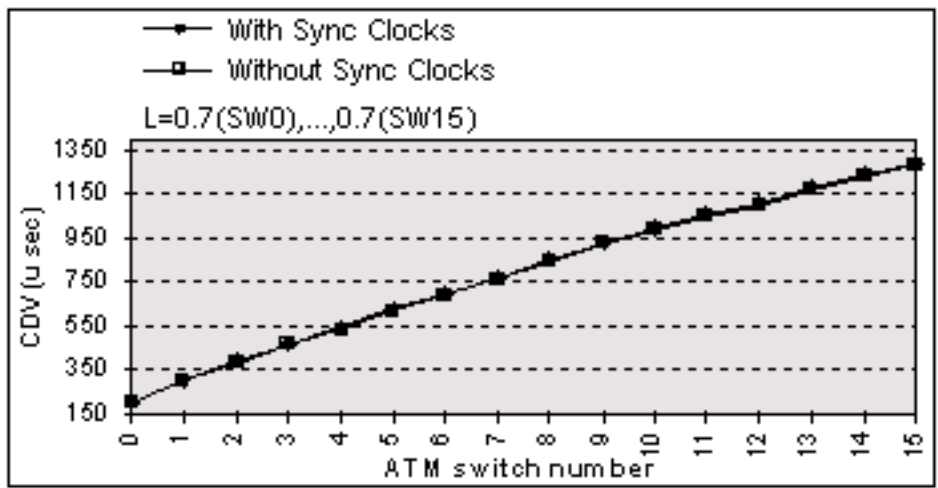

Figure 7. Cumulative CDV measured by using 16 ATM switches.

Both methods have advantages and disadvantages. The advantage with the synchronised clocks is that intermediate ATM switches do not have to process the information contained in the OAM cells. They simply relay the OAM cells without modifying or adding information. Thus, ATM switch implementations can be simple. One disadvantage is that for the reasons above mentioned, the capabilities of this measurement method are limited. For instance, it is not possible to measure the local cell transfer delay, as well as, the local cell delay variation with this method. Another 
disadvantage is that this method requires synchronised clocks at the measurement points to the same time of day. Otherwise, the direct measurement of cell transfer delays using time-stamped OAM cells will result inaccurate.

From the simulation results obtained, the second method (figure 4) presented in this work has the advantage that it can accurately measure the end-to-end CDV using time-stamped OAM cells, without the need for clock synchronisation at the measurement points, as required by the first method (figure 3). A possible disadvantage of this method is that each intermediate ATM switch must be able to monitor, process, modify, and to generate the OAM cells. This may increase the complexity of ATM switches. However, this increase in complexity may be justifiable as long as more measurements parameters and network statistics are required in ATM networks.

\section{ACKNOWLEDGEMENTS}

J. García wishes to acknowledge the support of Consejo Nacional de Ciencia y Tecnología (CONACYT) and Instituto de Investigaciones Eléctricas (IIE), México, in this research work.

\section{REFERENCES}

[1] Garvey A. \& Boyer P., "Cell Delay Variation Specification in ATM Networks", IFIP Modelling and Performance Evaluation of ATM Technology (C-15), Edited by H. Perros, G. Pujolle and Y. Takahashi, Elsevier Science and Publishers, 1993, pp. 305-324.

[2] Roberts J., Mocci U. \& Virtamo J., "Broadband Network Teletraffic : Performance Evaluation and Design of Broadband Multisenvice Networks", Springer-Verlag, Berlin, 1996.

[3] García-Hernández J. \& Ghanbari M., "Effect of Burstiness of the Background Traffic on the Cell Delay Variation of CBR an VBR Video in ATM Networks", Sixth IFIP Workshop on Performance Modelling and Evaluation of ATM Networks, Ilkley, West Yorkshire, UK, 20-22 July, 1998, pp. 17/1-10.

[4] Elbatt T.A., El-Henaoui S. \& Shaheen S., "Jitter Recovery Strategies for Multimedia Traffic in ATM Networks," IEEE GLOBECOM. Vol. 2, 1996, pp. 1202-1206.

[5] ATM Forum, "Traffic Management Specification version 4.0", 1996, April.

[6] ITU-T Recommendation I.610, "B-ISDN Operations and Maintenance Principles and Functions", 1993,March.

[7] García-Hernández J. \& Zhang. J., "Monitoring, Evaluation and Notification of the QoS in ATM Networks", Fourth IFIP Workshop on Performance Modelling and Evaluation of ATM Networks, 1996, pp. 43/1-10, Ilkley, West Yorkshire, U.K., July.

[8] García-Hernández J. \& Ghanbari M., "In-Service Monitoring of Quality of Service in ATM Networks using OAM cells", IEE Proceedings-Communications, Vol. 146, No. 2, UK, April, 1999, pp. 102-106.

[9] Farkouh S., "Managing ATM -based Broadband Networks", IEEE Communications Magazine, May, Vol.1, 1993, pp. 82-86.

[10] Breuer H., "ATM-layer OAM : Principles and Open Issues", IEEE Communications Magazine, September, Vol.1, 1991, pp. 75-78.

[11] Anderson J. \& Nguyen M., "ATM -layer OAM Implementation Issues", IEEE Communications Magazine, September, Vol. 1, 1991, pp. 79-81.

[12] García-Hernández J., "Management of the Quality of Video Services in ATM Networks", PhD Thesis, University of Essex, UK, 1999, April.

[13] ITU-T Recommendation I.356, "B-ISDN ATM Layer Cell Transfer Performance", 1993, November.

[14] Gruber J.G. "Performance and Fault Management Functions for the Maintenance of SONET/SDH and ATM Transport Networks", ICC'93, Vol. 3, 1991, pp. 1308-1314.

[15] Lewandowski W. \& Thomas C., "GPS Time Transfer", Proceedings of IEEE, Vol. 79, July, 1991, pp. 991-1000.

[16] BONeS DESIGNER User's Guide, version 3.6, Alta Group of Cadence Design Systems, Inc., California, USA, 1996, March. 


\section{Authors Byography}

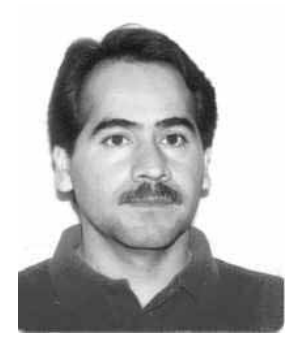

Joaquín García Hernández

Since 1986, Joaquin Garcia Hernandez is a full-time member of the research staff of the Unit of Control and Instrumentation at the Institute for Electrical Research (IIE), Cuemavaca, Mexico. He received the B.Sc. degree in Communications and Electronics from the National Polytechnic Institute (IPN), Mexico, in 1985; the M.Sc. degree in the Telecommunications and Electronics from CICESE Research Centre, Ensenada, B.C., Mexico, in 1991; and the Ph. D Degree in Electronic Systems Engineering from the University of Essex, England, in 1999.

He has published several national and international conference and journal papers on themes related to Quality of Service (Q0S), Asynchronous Transfer Mode Networks (ATM), Local Area Networks (LANs), Wireless LANs, and Mobile Networks, respectively. From 1991 to 1994 he was a Lecturer of several B.Sc. and M.Sc. Communications and Computer Networks courses at CENIDET, Cuernavaca, M exico, and since 2000 at ITESM Campus Cuernavaca, Mexico.

His main research interests are in Quality of Service, in Multimedia, Communications, Networks, Wireless and Mobile Networks.

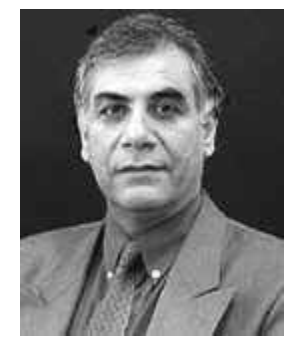

\section{Mohammed Ghanbari}

Is a professor in the Department of Electronic Systems Engineering with the main research interest in the areas of Video Networking. He graduated from Aryamehr University of Technology, Tehran, Iran, with a B.Sc. Degree in Electrical Engineering in 1970, M.Sc. in Telecommunications and Ph.D. in Electronics from the University of Essex, England, in 1976 and 1979, respectively. After a 10 years job in Radio and Television broadcasting, he started his academic career in 1986 as a Research Fellow, working on Video coding for Packet Networks. He was then appointed as a Lecturer at the Department of Electronic Systems Engineering, University of Essex in 1988 and promoted to Senior Lecturer and Reader in 1993 and 1995, respectively. He was appointed a personal chair in 1996.

He is best known for his pioneering work on two-layer video coding for ATM networks, now is known as SNR scalability in MPEG-2 video codecs. He has registered three international patents on various aspects of video networking. 